\title{
A REVIEW PAPER ON SOLAR POWER TREE
}

\author{
G. S. Karlekar \\ Asst. Professor, Department of Electrical Engg. \\ Ballarpur Institute of Tech., Ballarpur, India
}

\author{
Atique Sheikh, Abhishek Wasekar, Sharad Rakhunde \\ Student, Department of Electrical Engg. \\ Ballarpur Institute of Tech., Ballarpur, India
}

\begin{abstract}
We are living in $21^{\text {st }}$ century where energy demand is much higher. To fulfill this demand we use coal, oil as a fossil fuels for generation of electricity. But the use of this fuels creates lots of pollution which critically harms the living beings. After 40-50 years fossil fuels are going to reduce. Then the major problem will arise is how to generate electricity, so the solution on this problem is necessary. one of the best solutions on this problem is to produce electricity which can generate by using renewable forms of energy. Most efficient source of renewable energy is sun which is free of cost and easily available in nature. By using solar panels, we can generate pollution free electricity. Therefore, as an electrical engineer, we are introducing a simplest and latest technology solar power generated using "SOLAR TREE". one of main disadvantage of traditional solar system is that it required more space so, to solve this problem we are proposing solar tree which generate more electricity from less space. Our system has an advantage on other that it has rotating solar panels which can absorb equal amount of sunlight throughout the day. Here We are using monocrystalline panels which is more efficient than other panels.
\end{abstract}

\section{INTRODUCTION}

In all over the world, the rate of population increases fastly. Generation of energy is less as compared to energy demand. The fossil fuels and nuclear reactors are the main sources of power generation but these are non-renewable and pollute the environment. The renewable energy plays an important role in pollution free environment and it is the major alternative power from sun in comparison to other sources of renewable energies. Solar energy is the best option to generate the electricity which is pollution free, last for lifetime and easily available. We generate the power from sunlight by using solar panels. Most of generation is done using traditional system. In traditional system, land requirement increases and it is not easily available because of increase in the population day by day, so which creates a problem. The solution on this problem and getting more energy from less land is a" SOLAR TREE". A solar tree is an artificial tree with the solar panels are arrange in Fibonacci series manner.

Why we call these as solar tree? The natural tree produces their own food by the process of photosynthesis. In natural tree, leaves are producing food material for human beings likewise in solar tree solar panels are working as leaves and they absorb the sunlight and producing the energy for society.

Tree stands for:

\section{$\mathrm{R}=$ Renewable}

$\mathrm{E}=$ Energy and

\section{$\mathrm{E}=$ Electricity}

Our system has an exactly tree like appearance. Solar panels are connected at the top of branches of tree. The top most panel of this tree has tilting system which rotates according to the position of sun. using this tilting system, the top most panel can generate equal amount of electricity throughout the day. Our system is more efficient and effective than traditional system. It has a simplest tree like structure which can be easily installed for household purpose. By installing this system for the use of day to day life we can fulfill the energy consumption demand.so this will be a good way of pollution free energy method in poor countries.

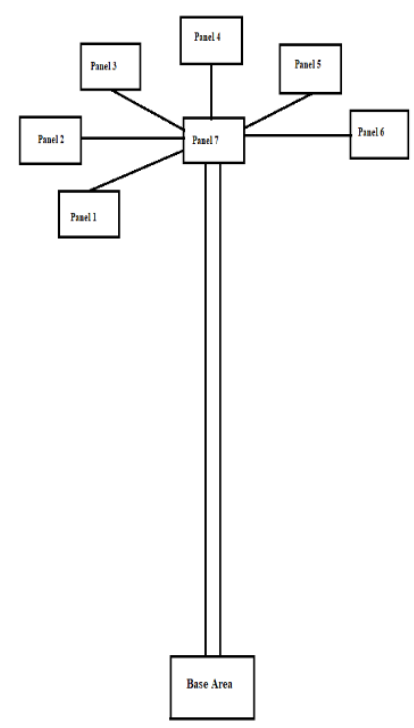

Fig. 1. Solar Power Tree

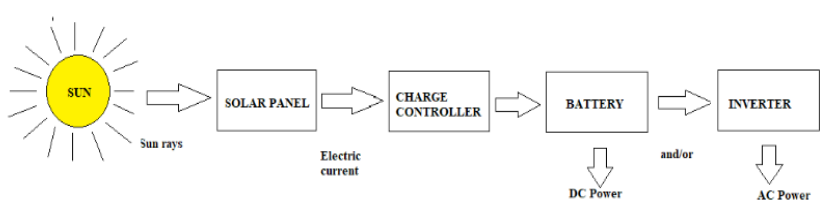

Fig. 2. Block Diagram of Solar Tree

\section{HISTORY}

- In 1800 solar energy plants developed. 


\section{International Journal of Engineering Applied Sciences and Technology, 2020 \\ Vol. 4, Issue 10, ISSN No. 2455-2143, Pages 106-108 \\ Published Online February 2020 in IJEAST (http://www.ijeast.com)}

- In 1839 Alexandre Edmond Bacquerel discovered the photovoltaic effect.

- In 1941 Russell ohl invented silicon solar cell.

- Based on solar cell work of Russell ohl, solar panels were made in 1955.

- $\quad$ Around 1883 the first genuine solar cell was built by Charles fritts.

\section{COMPONENTS OF SOLAR POWER TREE:}

solar tree consists of following components

\section{A. Solar panels:}

A solar panel is a series interconnected silicon cells joined together to form a circuit. In greater numbers the amount of power produced by these interconnected cells can be increased and used as an electricity production system. To make solar cells, the raw material silicon dioxide of either quartzite gravel or crushed quartz is first placed into an electric arc furnace, where a carbon is applied to release the oxygen. The products are carbon dioxide and molten silicon. When light energy strikes the solar cell, electrons are knocked loose from the atoms in the semiconductor material. If electrical conductors are attached to the positive and negative sides, farming an electrical circuit, the electrons can be captured in the form of an electric current that is electricity

\section{B. Pipes:}

solar PV modules are mounted on a single tall pole and the branches are connected to it. The branches of the solar tree are tilted at an angle 40-45 for acquiring more amount of sun rays. To get the required power for the small household purpose total of six branches are being installed containing solar panel at the tip and the top of the pole consists of one solar panel having tilting mechanism to till the topmost solar panel at different angles through the day.

\section{Battery:}

battery is used to store the power which is generated by the solar power tree. The rechargeable battery are lead-lead dioxide systems. The Separators and plates absorbed the dilute sulfuric acid electrolyte and immobilized. When the battery accidentally overcharged then it produces hydrogen and oxygen, special one-way valves allow the gases to escape thus avoiding excessive pressure build up otherwise, the battery is completely sealed and is, therefore, maintenance free, leak proof and usable in any position.

\section{Solar Charge controller:}

A charge controller limits the rate at which electric current is added to or drawn from electric batteries. It prevents overcharging and may protect against overvoltage, which can reduce battery performance or lifespan, it may also prevent completely draining a battery or perform controlled discharges, depending on the battery technology to protect battery life.

\section{E. Solar Tracker:}

A solar tracker is a device that orients a solar panel towards the sun. In this we use single axis solar tracker system. Single axis solar tracking system is the best solution for small PV system. due to solar tracking system solar panel can absorb equal amount of sunlight throughout the day. Solar tracking system is composed of well differentiated components the driving motor and tracking controller.

\section{WORKING OF SOLAR POWER TREE:}

solar panel is made up of small solar cells. When sunlight falls into the solar cells, they convert light energy into current or electricity. solar tree generates energy during day time and in night LED's of solar tree are automatically on and get off in the morning. This automated process is done by the sensors which are used in solar tree. Here we are using total seven solar panels. out of them six panels are fixed at top of the branch and the other one is rotating according to the position of sun. the rotation of solar panel is done by using DC motor. The DC motor rotates the solar panel using DC servo motor, so the solar panel receives maximum sunlight at each instant. out of the seven panels three panels are connected in parallel and the other three panels are also connected in parallel. Then remaining one panel and both the parallel connections are connected in series. And these panels connections are given to the charge controller. The charge controller is connected to the battery. The battery is used for storage. When sunlight falls on the solar panels generation of electricity takes place. Firstly, there are three panels which are connected in parallel and next three panels are also connected in parallel. Out of seven panels six are of same rating that is $10 \mathrm{~W}$ and remaining one is $5 \mathrm{~W}$. and the total output is $25 \mathrm{~V}$ and $1.71 \mathrm{Amp}$. And the output of solar tree is connected to charge controller which display voltage and it prevents overcharging and may protect against over voltage.

\section{CONCLUSION}

There are many ways to produces electricity. With the increasing population the demand of electricity increasing day by day. To fulfill this demand, we are introducing an easy and safe way of producing the electricity without harming the environment. Solar tree is the best option to produce more electricity in less space. this solar tree can be successfully installed in gardens, school, colleges, balconies of flats, streets, houses etc. our project completely fulfilling all the needs of electricity in gardens and houses, thus solar tree is the best solution towards the green energy and the solar tree concept is successfully work.

\section{ACKNOWLEDGEMENT}

Every project big or small is successful due to the efforts of the people who have always given their advice. We consider our privilege to express the respect and voice of gratitude to all those who guided us in completion of this project.

We wish to express sense of gratitude to our guide Mr. Gaurav Karlekar. Electrical Engineering Department Ballarpur Institute of Technology to give us guidance and valuable suggestions. We sincerely appreciate the inspiration, support 


\section{International Journal of Engineering Applied Sciences and Technology, 2020 \\ Vol. 4, Issue 10, ISSN No. 2455-2143, Pages 106-108 \\ Published Online February 2020 in IJEAST (http://www.ijeast.com)}

and guidance of all those people who have been helping in making this project a success.

We are honestly thankful to our friends for their help during the preparation of our project. We would like to thanks our institute and our faculty members.

\section{RESULT}

The solar tree is latest initiative towards the renewable energy. By occupying less space, we are producing much amount of electricity. Our solar system uses latest technology panels called as monocrystalline panels which is more efficient than others. Design of the solar tree is made in such manner that it grabs more sunlight to produce the electricity. We are using seven panels out of them first four are connecting in series and remaining three are connected in series these series connected panels are connected in parallel. These connections are producing ------amount of power which is easily fulfilling the basic demand.

\section{APPLICATIONS}

- In the field of golf courses and resorts.

- In urban and rural areas.

- Applicable in recreational parks, city parks.

- In penthouses, balconies, verandas, private gardens.

- Applicable on highways.

- In deforested areas.

- It is used for street lighting.

- It is also used for domestic supply.

- It is applicable for industrial power supply.

- It can also useful for continuous power supply.

- It is used in batteries charging of mobile phones, laptops, tablets.

- Wireless data transmission.

\section{REFERENCE}

- Sushma Gupta, Monish Gupta, (2015,3), "The Benefits and Application of Solar tree with Natural Beauty of Tree", Applied science Report, PSCI publications, 117-124.

- Elisavet Dimitrokalia, Jamie Mackrilla, Graham Jonesb, yorck Ramachersb, Rebecca Caina, (2015), "Moving away from flat solar panels to PV Trees: Exploring ideas and people's perceptions", "International Conference on Sustainable Design, Engineering and Construction, Procedia Engineering 1208-1216

- Baruch P. (1985) A two level system as model for a photovoltaic solar cell. Journal of Applied Physics. 57, 13427-1985

- Goyal RK, Illyas SM. (2005). Potential of Solar Thermal and Biomass Energy in Drying of agriculture produce. In proceedings of the $4^{\text {th }}$ Asia pacific drying Conference. 13-15 December, Kolkata India. 2, 901919.
- Mr. A P R Srinivas (Octomber-2016) "Design and Development of a SOLAR TREE", International Journal of Scientific and Engineering Research, Volume 7, Issue 10, ISSN 2229-5518

- Deepak M. Patil, Santosh R. Madiwal, “design and development of a solar tree

- "The Emergent Solar Tree" retrieved on 2015-03-15 from www.solartree.co/contact5.htm

- IJSRP-p2490.pdf: Idea to design a solar tree using nanowire technology

- Richard J. Komp, (2003) Practical Photovoltaics: Electricity from Solar Cells, Aatec publications, Third Edition Revised

- Jenny Nelson, (2003) The Physics of Solar Cells, Imperial College Press

- E. A. Umoh and A. A. Luggage, (2019) "Contextualizing hazard mitigation policy for electricity grids in the Sudan Sahel Region of Nigeria," Energy policy, vol. 124, pp 135-43

- M. O. Oseni, (2014,7) "Self -Generation and Household' Willingness to pay for Reliable Electricity Service in Nigeria, "Energy Journal, vol. 38, no. 4, pp. 94-165

- $\quad$ K. M. Powell, K. Rashid, K. Ellingwood, J. Tuttle, and B. D. Iverson, (2017) "Hybrid concentrated solar thermal power system: a review", Renewable and Sustainable Energy Reviews, pp 215-37

- A. K. Akella and S. Das, (2017), "Technical and Socio-Economic Aspects of Hybrid Renewable Energy Sources: A Step-by-Step Approach," International Journal of Applied Engineering Research, vol. 12, no. 21 , pp.11228-11241

- S. C. Wind and Waves, (2017) and the Sun: The Rise of Alternative Energy. Cavendish Square Publishing, LLC. 